Global Conferences Series:

Social Sciences, Education and Humanities (GCSSSEH), Volume 2, 2019

The $2^{\text {nd }}$ International Conference on Sustainable Development \& Multi-Ethnic Society

DOI: https://doi.org/10.32698/GCS.0197

\title{
Implementation of Historical Thinking Skill Among Malaysian Students using History Textbook: Concept, Issues and Challenges
}

\author{
Hedya Sasha Binti Abdullah", Mohd Mahzan Bin Awang ${ }^{2}$ \& Abdul Razak Ahmad ${ }^{3}$ \\ ${ }^{123}$ Faculty of Education UKM, MALAYSIA \\ E-mail: hedyasashaabdullah@gmail.com
}

\begin{abstract}
Changes in history education in secondary schools in Malaysia with the introduction of the Primary School Standard Curriculum (KSSR) and the Secondary School Standard Curriculum (KSSM) aimed at producing students who master the history by emphasizing the integration of the components of knowledge, skills and values. In Malaysia, history textbook not only hold important roles such as a medium to transport factual knowledge but also as historical images of nation in order to cultivate society values among youngsters and future generations of Malaysian. In fact, history textbook is the most trusted source of information and being used widely as the main reference of historical content knowledge among history teachers and students. Apart from that, history textbook not only as reflection of Malaysia's aspirations but also to implement meaningful skill which should be mastered by students which is known as Historical Thinking Skills (HOTS). As recent studies found that, not all of the skills were able to be implemented well in the classroom that lead to question what caused this problem to emerge in today history teaching and learning. There were many suggestions from different parties for a re-evaluation of the quality of textbook in order to maximize teaching and learning in this 21 st century education especially in implementation of Historical Thinking Skills (HOTS) .This paper provides concept of the roles of history textbook and the concept of Historical Thinking Skills (HOTS). The discussion also involved in common issues regarding on implementation of Historical Thinking Skills (HOTS), as well as exploring the challenges in implementation of Historical Thinking Skills (HOTS) using history's textbook among students and teachers in Malaysia.
\end{abstract}

Keywords: Historical Thinking Skills, History’s textbook, concept, issues, challenges

\section{Introduction}

Copyright $\odot$ 2019, the Authors. Published by Redwhite Press.

This is an open access article under the CC BY-NC license

(http://creativecommons.org/licenses/by-nc/4.0).
As a key aids and a premier source of information, textbooks are important in the education system, especially for history education. The teachers use textbooks as a teaching material in teaching and learning and also as the main guidance and 
syllabus for each subject that should be taught in the classroom. According to Yahya Azizi et al, (2007), a textbook can be likened to a reflection of society's values, hopes and aspirations of Malaysia. Through textbooks, philosophy, goals, objectives and principles are embodied in the educational curriculum. According to Wan Mohammad (1998), before textbooks were distributed to clients such as the store books and school, the textbook will be screened at four levels of evaluation to meet the characteristics of a good text book and the syllabus should be in line with the content, correct and simple language, appropriate graphics and attract students to use textbooks, and provided exercises can match the skill possessed by students. Generally, each primary school will use minimum of 10 textbooks and history textbook is one of them.

Khoo Kay Kim (1995) recognized that the stimulus in history education plays an important role. This is because the history curriculum are loaded with knowledge and values, which enables critical thinking and rational carried out by themes, terms, ideas, arguments, insights, interpretations of spacetime, cultural factors and the chronology of events. CO (1990) stated that teaching history involved the relationship between human and social values as well as any changes that occur in society and in fact this matter was in line with the objectives of history education to foster History Thinking Skills (HTS) based on the acquisition of facts, mastery of ideas and methodologies. Teacher's role in developing thinking skills among students absolutely must be given special attention. According to Abdul Razak (1999) in order to attract students to enjoy learning history should be start with clarity of the concept, assess the reasons, the chronology of events and make the interpretation by providing examples of which are close to existing knowledge and experiences by the students. This was in keeping with the fact that education is no longer just to teach what students are expected to know but how they know (Eggan \& Kauchak 2001). Learning History supposedly not dependent on textbooks alone, but to what extent the textbook will be able to help students to understand the beneficial of learning history, especially in applying HTS become the core matter. Thus it is important to ensure that history textbooks is able to assist teachers to implement HTS during lessons so that the process of thinking can be developed to be more meaningful to the students and to achieve educational goals of history. However, there were many issues and challenges that need to be overcome before teachers will be able to use the textbooks as the main source of teaching history in the classroom especially in promoting HTS and implement it among the students.

\section{Textbooks}

Textbooks are used in a particular field of studies are also known as standard books and compiled by experts in the field to explain subject matter based on the goals and objectives of the learning process. It must be easily read and understood by readers in schools and higher education institutions to ensure teaching and learning carried out effectively. Ryan McFall (2005) in his statement explaining "A textbook written at a high level assumes a reasonable amount of prior content knowledge, while a low-level textbook often seeks to" water down "the concepts so that readers new to the field can understand them ". The preface of the textbook and instructions that can be used by teachers is as a mechanism to open up the universe and insights about the contents of the textbook. (Suparti, Sugiran and Sulisstiyono 2010). Muslich (2010) stated that the textbooks are teaching aids that are used as a reference by students at some stage as a path of learning (instructional) related to area of certain studies .That is why, textbooks as standard book compiled by experts in the field that is equipped with means of learning and is used as a key pillar in the learning process. As mentioned, textbooks did hold significant roles in order to deliver the content of knowledge and to inbuilt values among students. That was why, teachers need to be trained and mastered the skill to make intelligent use of textbooks in order to help the students into further explorations of knowledge (Maxwell,1985).

\subsection{The Role of School Textbook as a Transport Factual Knowledge}

School textbook does not only function as reading tool as it has numerous functions (Hummel, 1988). As the very first printed word material that will be introduced to young leaners, textbook plays important roles and big significant in developing country such as Malaysia. Textbook well known as the best source of factual knowledge and become primary source in the classroom. Bierman et.al (2006) emphasized that for ages, the printed textbook has been means to transport factual knowledge which has been organized and distributed to students before the lesson took part on early year of schooling. Moreover, textbook not only functioning as source of knowledge but also functioning as mechanism for initial learning and as a reference or knowledge. Thus, textbook not only as the first source for reading materials but also as the main mechanism in early learning and reference knowledge by teachers and students. From there, textbook creates communication and interaction in the classroom between teacher and students or between students and students or between students and the textbook.

As globalization took part in this digital era and technology has made teaching and learning style become more convenient with the help of electronic media, the role 
of textbook as printed material that been used for decades seems eroded. Textbook likely less favorable than e-book that can be easily excessed through gadget such as tablet and computer and this matter raise the question how textbook fit students' need and cultural in nowadays learning environment. Bierman and colleagues (2006) argued that textbooks are not dead but their roles and appearance are changing into more convenient, user friendly and more interactive. The most important thing in this drastic change, textbook still keep functioning as the main source for teaching and learning but also being improved with many roles such as a guide, interweaving and coordinating a variety different learning exercise and organizing hub in more integrated learning environment. Bierman et.al., (2006) even mentioned that "the goal is to retain the core stability ad authority that make textbook so valuable while at the same time to provide the flexibility, timeliness, and inquiry-focused approach that the web and other electronic resources offer". How fast the changes have been made on the textbook, it never can change it superior roles as the main source of knowledge in teaching and learning.

\subsection{The Role of Textbook as a Medium of Transmission of Values}

Textbook reflects the ideology and aspiration in education that will be carried out during teaching and learning in the classroom. Textbook is not only meant to spread knowledge but also to aim in building the core skills in history education which is known as Historical Thinking Skills. Apart from that, textbook not just a book that only contain knowledge and facts but it also contains society values that need to be taught and practiced by Malaysian young generations. This is very important task in order to build a nation with good cultures and values that reflect patriotism, sense of belonging and sense of togetherness among Malaysians. Crawford (2004) states that school textbooks were important tool in efforts to build the ideologies, to impart knowledge and values that are considered essential in society. Whereas Apple (1993) states that textbooks were something that, designed and authored by people in significant interest. The textbook is therefore a powerful learning tool for disseminating knowledge, developing skills, cultivating values and shaping students' interaction with the world.

\section{Historical Thinking Skills (HTS)}

Historical Thinking Skills refers to thinking skills related with history (MOE, 2003). Historical Thinking Skills has been used since the discipline of history was founded as stated by Collingwood (1946) in (Tholfsen 1967). The components contained in the structure of the history discipline which helps students see the empathy and analyzing how people use time, space, change and chronology. This will provide a critical understanding of history and imagination. Indirectly, History Thinking Skill helps students to explore complex ideas and abstract with the guidance of teachers via cognitive processes that occurred. Through these skills students will learn how historians use an authentic source to reconstruct past events to determine the significance of a date, characters, events, locations and activities of the human past. Students will learn to understand the characteristics of history so that they can improve their thinking skills into more critical and analytical. Thought it is a step to review and to consider the information carefully. This requires complex ability which includes the ability to draw conclusions from the data obtained. While the results give someone a new idea (Dewey 1993).

There are five skills in Historical Thinking Skills to be mastered, nurtured and developed among students as suggested in the history curriculum by Department of Curriculum Development (2016) are as follows:

\subsection{Understanding Chronology}

Understanding chronology means looking at the past, present, and future in the context of a historical event. Next students are taught the skills to understand the concept of time according to the progress of a civilization while also understanding the past by labelling events in times periods without specifying the year.

\subsection{Exploring Historical Evidence}

Exploring historical evidence involves the skill of identifying the first and second sources by comparing the two. This can stimulate the thinking of the history of a student while also understanding the problem of history and its intrinsic nature.

\subsection{Interpretation}

Interpretation means to interpret a historical event by providing reviews and conclusions. Students are made aware of the differences between the historical facts and the interpretation of history by recognizing that the two are related to each other.

\subsection{Imagination}

Imagination is an attempt to engage students in historical events. This type of skill is visual imagination and empathy

\subsection{Rationalize}

Rationalize involves the use of the mind and the proper consideration in resolving a question arising from the historical events. This effort requires students to collect data, 
make hypotheses, determine significant evidence and draw inferences from the data collected.

\section{Issues, Problems and Challenges of the applications of Historical Thinking Skills Using Textbook}

\subsection{Lack Of Efficient Skill In Using History Textbook Among The History Teachers}

Studies conducted by Aini Hassan (1999) and Balakrishnan (2002) showed that many teachers read textbooks when teaching without taking steps to instruct the students to understand the concept and information exploration. In fact, a study by Megat S "Adan Megat Salleh (2004) of 26 history teachers in Perak Tengah. The study found 77.5 percent or 20 of the 26 teachers only use textbooks in teaching and learning in the classroom. This means that the use of the textbook as the primary source of history is absolutely undeniable, but so studies Abdul Razaq et al. (2013) found that teachers of history are not fully proficient in the use of textbooks, especially history textbooks in adapting content for the purposes of the application of Historical Thinking Skills. A study by Azwani Ismail (2012) suggests that teachers whose were relied on textbooks led to dysfunction of teacher roles as the expert of knowledge of history. They prefer to use textbooks but it is more widely used for the purpose of memorization. Zarina study (2013) showed that teachers relied heavily on history textbooks only encouraged them to maintain the traditional learning styles such as memorizing and remembering historical facts for examination purposes. Teachers had been strongly critized for using the textbook as their "only resource in the classroom' that caused to limited outcome of teaching and learning during training program. The reason teacher are relying heavily on the textbook due to lack of other instructional material and worse part was, they do not use the textbook effectively (Razia\& Roshni 2007) Teachers are more dependent on the textbook as a source of facts and materials of instruction (Barton \& Levstik, 2004) but the skills to use textbooks are not fully controlled thus failing to apply the proper skills Historical Thinking pace in the history education.

\subsection{Lack of Knowledge and Practise on Historical Thinking Skill Among The History Teachers}

Department of Curriculum Development states that there are six elements in the structure of the discipline of history, namely (1) inquiry in history, (2) collecting sources, (3)Historical Thinking Skill, (4) an explanation of the history, (5) the understanding of history, and (6 ) empathy. To ensure that students can master the third skill, Historical Thinking Skill positioned as one of the important areas in the
Primary School Standard Curriculum in order to help students to gain knowledge and formulating the events that took place with the best assessment supported by the evidence and concrete arguments. Ahmad Rafaai Ayuda (2011) stated that it is important to know and understand the basic concepts of history before students are exposed on the characteristics of the history, chronology of events, the causes of an event to make a comparison, interpretation and make the rationalization of a historical event. Zarina Mohd Yassin (2013) said it is essential for history teacher to master the Historical Thinking Skill in order to have a positive impact on students and create a fun situation during the teaching and learning of history.

However, according to Baharuddin Jabar(2007) shows the execution of Historical Thinking Skills among history teachers in six schools in the district were in a moderate level which is at 45.5 percent. In the same survey, the findings show that the implementation of Historical Thinking Skills in teaching history teachers was vary among the skills resulted chronology skill at 46.1 percent, imagination skill at 18.6 percent, exploring the evidence 67.4 percent, making interpretation at 36.3 percent and rationalize at 59 percent. Lack of knowledge in Historical Thinking Skills limited them to apply these skills to students and students will not be able to understand clearly the content of the subject. Whereas in 2018, a study done by Muhammad Yazid Khalil discovered that Historical Thinking Skills among primary school teachers were at average .According to the study ,Yazid Muhammad Khalil (2018) found that the mean score for the whole construct of Historical Thinking Skill was 3.69 and the standard deviation of 0604 . Chronological skill, imagination skill and rationalize skills were at a high level, mean of 3.69 and standard deviation from 0685 to 3.77 and a standard deviation of 0.614 . Exploring historical evidence skill and interpretation skill were at a moderate level where the results showed a mean value of 3.65 and a standard deviation of 0.602 . Even in the Federal Inspectorate Executive Reports (2008, 2009, 2010) indicating the history teachers still do not implement Historical Thinking Skill element during the teaching and learning session in the classroom. Most of the reasons given by teachers of history they have little knowledge about Historical Thinking Skills limited the performance in implementation those skills (Anuar Ahmad, 2005; Ahmad Rafaai 2010). According to Zarina Mohd Yassin (2013), among other obstacles to implement Historical Thinking Skill included teaching workload, lack of confidence, lack of understanding and lack of resources.

\subsection{Teachers' Limited Pedagogical Content Knowledge on History Education}


Shulman (1987), Aini Hassan, (2001) and Burnet Bisset (2006) have confirmed professional teachers should be experts and skilled in pedagogical knowledge so that teaching and learning can be developed in a holistic and credible and attract students to approach teaching and learning. Teachers are no longer solely responsible for developing channel information but the mind, shaping the personality and knowledge. One of major factors that caused to less effective use of textbook among teachers was their perceptions and attitude towards the use of textbook and lack of content knowledge in teaching history. In fact, the majority of history teachers still adopt the traditional approach to teaching and learning (Aini Hassan, 1998; Siti Hawa Abdullah, 2008). Melissa study (2009) found that a history teacher still use traditional teaching methods due to their lack of knowledge and mastery of the skills Thought History. There among history teachers who still have a sense of phobias, fear and negative to accept change because they prefer the old method that is based on textbooks, handouts or written on green board only (Azwan Ahmad et al., 2005). Students become passive about historical understanding because not developed thinking in history as a result of passive learning style. This practice led to boredom and decreased students interested in history and thus failed to apply the thinking skills among students in history. Methods commonly used are textbooks, workbooks, exercises that are part of the traditional method of creating a R \& D is only one direction that fail to raise students' thinking skills in history (Ahamad uterus 2012; Zarina Mohd 2013; Ahmad Rafaai Ayuda, 2013; Abdul Razak Ahmad and Mohd Mahzan 2015). Yilmaz (2008) studied the teaching methods used by teachers of history for conceptualizing history involving 12 experienced teachers for 16 years of teaching in the subjects of history and graduated from 3 cities in the southeastern United States. The study showed that a majority among teachers showed no understanding of the concept of history and do not emphasize the interpretation that an essential component of the history of education skills. There is a need to diversify its aspects in the pedagogical methods enable students to understand the history and attract students to be more actively involved in the P \& C (Abdul Rahim Abdul Rashid 1989, 2000; Hazril Jamil 2000) Thus, insufficient in pedagogical content knowledge allowed teachers to do not make use of information or activities provided in the textbook as best as they could and this matter eroded the main purpose of textbook as the source of factual knowledge in the classroom.

\subsection{Examination-Oriented Teaching Style}

Examination encourages teachers spend most of history syllabus as preparation for examination purpose(Wan Ilyas 2001). The system emphasizes on academic performance in examination more than to achieve the real objective of teaching history history (Khoo Kay Kim, 2015). A study by Azwani Ismail (2012) through interviews conducted with teachers showed that they emphasized the used of textbooks compared than other historical sources to attract students interest in learning history. Time constraint and examinations led them to emphasize the input of textbooks compared to other sources.This situation showed that teachers give priority to examination performance compared to historical understanding especially in applying Historical Thinking Skill. Knowledge of subject matter were less effective because the memorization of facts had caused the students become passive because they are not actively involved in teaching and learning. As result, many students assumed that history was a boring subjects (Abd Rahim, 1999; Abdul Razak 2000; Ariegusrini \& Mohd Johdi 2009 ; Maher et al., 2009; Saunders-Stewart et al., 2012; Khoo 2013). Disorders and neglecting the acquisition of Historical Thinking Skills cause the students will not be able to feel and appreciate the pleasure of learning history. History was expressed as dull, dead objects, history rewind the country (Johdi Mohamad Abdul Razaq Ahmad Rafaai 2009) is often called. Thus, Historical Thinking Skill less applied in its history in the classroom impact of exam-oriented teaching style.

\section{Conclusion}

Teaching and learning process in education lies in several aspects such as the selection of teaching materials (Combs 2009). Textbook play an important role for students and teachers for teaching and learning to take path. As education system was in building process has led to very great importance of text books and play important roles for all parties (Affandi 2006). Thus, the use of textbooks play a very important role in determining student achievement in mastering Historical Thinking Skill. This is because, the book is the primary reference text approved by the Ministry of Education and must be owned by all pupils (Aisha, 2017). However, to ensure that students acquire knowledge about historical facts through the use of textbooks, educational history is not merely to impart knowledge about the "knowledge what" in fact, history also serves to help students master Historical Teaching Skills of "knowledge how ". Hence, in order to achieve the objective of teaching History especially in practising Historical Teaching Skills among Malaysian students, it is very important to overcome all the issues and challenges that had been arose and enhances the usability of textbooks among history teachers in Malaysia.

\section{References}

[1]Abdul Razaq Ahmad. 2010. The Acquisition of Conceptual Understanding of Historical Thinking in the 
Context of multi-ethnic students in Malaysia. Historia: Jurnal Pendidik dan Peneliti Sejarah, 10(2).

[2]Anuar Ahmad dan Nelson Jinggan. 2015. Pengaruh Kompetensi Kemahiran Guru Dalam Pengajaran Terhadap Pencapaian Akademik Pelajar Dalam Mata Pelajaran Sejarah. Jurnal Kurikulum \& Pengajaran Asia Pasifik, Vol.3, No.2.

[3]Crawford, K. (2004). Inter-cultural education: The role of school textbook analysis in shaping a critical discourse on nation and society. Paper presented at the Pacific Circle Consortium 27th Annual Conference, Hong Kong, Institute of Education.

[4]Combs, B. 2009. Mengajar Secara Efektif. Terj. Siti Aishah Mohd. Elias. Kuala Lumpur: Institut Terjemahan Negara Malaysia Bhd.

[5]Cooper, H and Dilek, D. 2004. Children's Thinking in History: Analysis of a History Lesson Taugh to 11 years Old at Ihsan Sungu School, Istanbul. International Journal of Historical Learning, Teaching and Research, 4(2).

[6]Drake, F. and Brown, S.D. 2003. A Systematic Approach to Improve Students' Historical Thinking. The History Teacher. 36(4).

[7]Department of Curriculum Development. 2016. Standard Document of Curriculum and Assessment of History Subject

[8]Kaziva, M. 2019. Hubungan Penerapan Elemen Kemahiran Pemikiran Sejarah dalam Proses Pengajaran dan Pembelajaran terhadap Pencapaian Mata Pelajaran Sejarah dalam kalangan Murid. Jurnal Kurikulum \& Pengajaran Asia Pasifik, Vol.7, 1.

[9]Khoo Kay Kim. 2007. Falsafah Sejarah: Ke arah mengembangkan unsur patriotisme dan kenegaraan. Prosiding seminar kebangsaan falsafah pendidikan ke arah pemantapan gagasan dan wawasan negara. Kuala Lumpur: Universiti Malaya.

[10]Lisa Yip Shukye. 2014. Kajian Tinjauan Kesediaan Guru-guru Sejarah Menerapkan Kemahiran Pemikiran Sejarah dalam kalangan Murid-murid. Jurnal Pendidikan Kent, Bil.13/2014.

[11]Lee, P. and Ashby, R. 1999. The Pittsburg Conference on Teaching, Knowing and Learning History. Teaching History.

[12]Mahadi, M. A., \& Shahrill, M. 2014. In pursuit of teachers $^{\text {ee }}$ views on the use of textbooks in their classroom practice. International Journal of Education, 6(2)

[13]Mahadi, M. A., \& Shahrill, M. 2014. Identifying The Issues From History Textbooks Research. Proceedings of SOCIOINT14- International Conference on Social Sciences and Humanities.

[14]Muhamad Yazid Bin Khalil. 2018. Tahap Pengetahuan Guru Sejarah Sekolah Rendah Dalam Kemahiran
Pemikiran Sejarah. Retrieved from https://upikpolimas.edu.my/conference/index.php/icompe x/icompex_2018/paper/viewFile/381/245 (9 Sept 2019).

[15]Rosy Talin. 2014. The Teaching of History in Secondary Schools. International Journal of Social Science and Humanities Research, 2(3).

[16]Razia \& Roshni.2007. Effective Use of Textbooks: A Neglected Aspect of Education in Pakistan, Journal of Education for International Development 3:1

[17]Rosy Talin. 2016. Why Historical Thinking Skills was not there? International Journal of Learning and Educational Research, Vol.15, No.3.

[18]Sharifah NorPuteh, Nooreiny Maarul, \& Elisabeth Tak. 2010. Students' Perception of the Teaching of Historical Thinking Skills. Pertanika Journal Social Science \& Humanities, 18(S).

[19]Siti Hawa Abdullah. 2008. Takrif dan Ciri-ciri Pemikiran Sejarah. Pendidikan Sejarah, 9(1).

[20]Wan Mohamad Wan Muda. 1998. Seminar Penulisan dan Penilaian Buku-Buku Teks. Kuala Lumpur: Biro Buku Teks, Kementerian Pendidikan Malaysia.

[21]Ying, C. C., \& Young, K. (2007). The centrality of textbooks in teachers ${ }^{\text {ee }}$ work: Perceptions and use of textbooks in a Hong Kong primary school. The AsiaPacific Education Researcher, 16(2).

[22]Yong, B. C. S. (2010). Can students read secondary science textbooks comfortably? Brunei International Journal of Science and Mathematics Education, 2(1).

[23]Zahara Aziz \& Nik Azleena Nik Ismail. 2007. Kajian Tinjauan Kesediaan Guru-Guru Sejarah Menerapkan Kemahiran Pemikiran Sejarah Kepada Para Pelajar. Jurnal Pendidikan, 32(2007). 